\title{
PENINGKATAN HASIL BELAJAR IPS DENGAN MODEL PEMBELAJARAN KOOPERATIF TIPE TEAM GAMES TOURNAMENT BERBANTUAN MEDIA VISUAL PADA KELAS VII-5 SMP MUHAMMADIYAH PALANGKA RAYA
}

\section{Oleh}

\author{
Sapti Chusniati ${ }^{1}$, Aidin Najihi ${ }^{2}$
}

Email: Aidin Najihi@yahoo.com

\begin{abstract}
This study aims to find out: How learning activities and improving student learning outcomes by using the Team Games Tournament Cooperative learning model (TGT) Assisted by Visual Media in class VII-5 of Palangka Raya Muhammadiyah Middle School. This research is a classroom action research (CAR). The number of research subjects was 23 students. The results of this study are: There is an increase in student learning activities, namely the score of learning activities of students in the second cycle there are 21 students who get a score of 003.00 and 2 students who get a score of 003.00 with an average score of 33,36 , so that the learning activities of students in the second cycle have been said to be good or have achieved indicators of success. learning outcomes of Social Sciences (IPS) when Pre Test obtained an average value of 39.34 with completeness in classical $4.34 \%$. In the post test the first cycle obtained an average value of $53.47 \%$ with completeness in classical $30.43 \%$. And the post test cycle II increased with an average value of 81.30 with completeness in classical $91.30 \%$.
\end{abstract}

(C) Muhammadiyah University Palangkaraya

Keywords: Model Team Games Tournament, Visual Media, Social Studies Learning Outcomes

\begin{abstract}
ABSTRAK
Penelitian ini bertujuan untuk mengetahui: Bagaimana aktivitas belajar dan peningkatan hasil belajar peserta didik dengan menggunakan model pembelajaran Kooperatif Tipe Team Games Tournament (TGT) Berbantuan Media Visual pada kelas VII-5 SMP Muhammadiyah Palangka Raya. Penelitian ini merupakan penelitian tindakan kelas (PTK). Jumlah subjek penelitian sebanyak 23 orang peserta didik. Hasil penelitian ini yaitu: Ada peningkatan aktivitas belajar peserta didik yaitu skor aktivitas belajar peserta didik pada siklus II terdapat 21 orang peserta didik yang mendapat skor $\geq 3,00$ dan 2 orang peserta didik yang mendapat skor $\leq 3,00$ dengan skor rata-rata 33,36, sehingga aktivita sbelajar peserta didik pada siklus II sudah dikatakan baik atau telah mencapai indikator keberhasilan. hasil belajar Ilmu Pengetahuan Sosial (IPS) saat Pre Test memperoleh nilai rata-rata 39,34 dengan ketuntasan secara klasikal 4,34\%. Pada post test siklus I memperoleh nilai rata-rata $53,47 \%$ dengan ketuntasan secara klasikal 30,43\%. Dan pada post test siklus II meningkat dengan nilai rata-rata menjadi 81,30 dengan ketuntasan secara klasikal 91,30\%.
\end{abstract}

(C) Universitas Muhammadiyah Palangkaraya

Kata kunci: Model Team Games Tournament, Media Visual, Hasil Belajar IPS

Sapti Chusniati ${ }^{1}$ Universitas Muhammadiyah Palangkaraya

Aidin Najihi ${ }^{2}$ Universitas Muhammadiyah Palangkaraya

ISSN : 2520-1923 


\section{PENDAHULUAN}

Pendidikan merupakan investasi jangka panjang yang memerlukan usaha dan dana yang cukup besar, hal ini diakui oleh semua orang atau suatu bangsa demi kelangsungan masa depannya. Demikan halnya Indonesia menaruh harapan besar terhadap peserta didik dalam perkembangan masa depan bangsa ini, oleh karena itu dari sanalah tunas muda harapan bangsa sebagai generasi dibentuk.

Sebagaimana tercantum dalam Undang-Undang No.20 Tahun 2003 Pasal 3 yang berbunyi:

Pendidikan nasional berfungsi mengembangkan kemampuan dan membentuk watak serta peradaban bangsa yang bermartabat dalam rangka mencerdaskan kehidupan bangsa, bertujuan untuk berkembangnya potensi peserta didik agar menjadi manusia yang beriman dan bertakwa kepada Tuhan Yang Maha Esa, berakhlak mulia, sehat, berilmu, cakap, kreatif, mandiri dan menjadi warga negara yang demokratis serta bertanggung jawab.

Hamalik (2007:32) menyatakan bahwa: Pembelajaran IPS adalah menemukan konsep-konsep yang cocok untuk dilatihkan pada anak seperti termuat dalam standar kompetensi lintas kurikulum yang meliputi memilih, memadukan dan menerapkan konsepkonsep, pola struktur dan hubungan.

Hasil belajar berkaitan dengan pencapaian dalam memperoleh kemampuan sesuai dengan tujuan khusus yang direncanakan. Dengan demikian, hasil belajar adalah kemampuan yang diperoleh anak setelah melalui kegiatan yang membawa perubahan-perubahan yang terjadi pada diri peserta didikbaik yang menyangkut aspek kognitif, afektif, dan psikomotorik sebagai hasil dari kegiatan belajar.

Model pembelajaran kooperatif adalah model pembelajaran yang menggerakan peserta didik berinteraksi dengan teman-teman sebayanya secara aktif dan positif, model pembelajaran kooperatif bekerja dalam sebuah kelompok yang terdiri dari tiga atau lebih anggota. Pembelajaran kooperatif merupakan bentuk pembelajaran dengan cara peserta didik belajar dan bekerja dalam kelompok-kelompok kecil secara kolaboratif yang anggotanya terdiri dari empat sampai enam orang peserta didikdengan struktur kelompok yang bersifat heterogen.Model pembelajaran kooperatif yang digunakan adalah model pembelajaran kooperatif tipe Team Games Tournament (TGT) adalah salah satu tipe model pembelajaran kooperatif yang mudah diterapkan, melibatkan aktivitas seluruh peserta didik tanpa harus ada perbedaan status, melibatkan peran peserta didik sebagai tutor sebaya dan mengandung unsur permainan dan reinforcement.

Menurut Anita dkk (2008:15) menyatakan bahwa: Hasil belajar adalah perubahan perilaku atau tingkah laku seseorang yang belajar akan berubah atau bertambah perilakunya, baik berupa pengetahuan, keterampilan atau penguasaan nilai-nilai (sikap). Perubahan perilaku sebagai hasil belajar ialah perubahan yang dihasilkan dari pengalaman dan tempat proses mental dan emosional yang terjadi. 
Menurut pendapat Merry (2015:13) berpendapat bahwa: Indikator hasil belajar adalah perubahan tingkah (aspek yaitu aspek kognitif, afektif, dan psikomotor) perubahan terjadi kearah yang positif, perubahan relatif menetap dan dialamisendiri oleh peserta didik.

Sedangkan menurut Arend (Trianto, 2014:53) menyatakan bahwa: Model pembelajaran adalah mengarah pada suatu pendekatan pembelajaran tertentu termasuk tujuan belajar tertentu dan berfungsi sebagai pedoman bagi perancang pembelajaran dan para guru dalam merancang dan melaksanakan pembelajaran.

Menurut Erickson (Komalasari, 2013: 62) mengemukakan bahwa: Pembelajaran kooperatif adalah strategi pembelajaran yang mengorganisir pembelajaran dengan menggunakan kelompok belajar kecil dimana peserta didik bekerja sama untuk mencapai tujuan pembelajarandan meningkatkan kemampuan hubungan sosial, menumbuhkan sikap menerima kekurangan diri dari orang lain serta dapat meningkatkan harga diri.

Menurut Komalasari (2013:67) menyatakan bahwa: Model TGT adalah salah satu tipe atau model pembelajaran kooperatif yang mudah diterapkan, melibatkan aktivitas seluruh peserta didiktanpa harus ada perbedaan status, melibatkan peran peserta didiksebagai tutor sebaya dan mengandung unsur permainan serta reinforce.

Sedangkan menurut Ahmadi (2011: 63) menyatakan bahwa: Pembelajaran kooperatif model TGT adalah salah satu tipe atau model pembelajaran kooperatif yang mudah diterapkan, melibatkan aktivitas seluruh peserta didik tanpa harus ada perbedaan status, melibatkan peran peserta didiksebagai tutor sebaya dan mengandung unsur permainan dan reinforcement.

Media menurut Fleming (Azhar Arsyad, 2013:3) menyatakan bahwa: Media adalah penyebab atau alat yang turut campur tangan dalam dua pihak dan mendamaikannya, dengan istilah mediatormedia menunjukan fungsi atau perannya yaitu mengatur hubungan yang efektif antara dua pihak utama dalam proses belajar peserta didik dan isi pelajaran.

Menurut Azhar Arsyad (2013:103) ada beberapa macam media yaitu:

1. Media Berbasis Visual.

2. Media Berbasis Audio Visual.

3. Media Berbasis Komputer.

4. Media Berbasis Komputer dan Interactive Video.

5. Media Microsoft PowerPoint.

6. Media Internet.

Menurut Azhar Arsyad (2013:102) menyatakan bahwa: Media visual adalah visualisasi pesan, informasi atau konsep yang ingin disampaikan kepada peserta didik dapat dikembangkan dalam berbagai bentuk seperti foto, gambar/ilustrasi, sketsa/gambar garis, grafik, bagan, chart, dan gabungan dari dua bentuk atau lebih.

\section{METODE PENELITIAN}

Dalam penelitian ini metode yang sesuai digunakan untuk meningkatkan hasil belajar peserta didik yaitu penelitian tindakan kelas. Penelitian 
Tindakan kelas (PTK) dalam bahasa inggris dikenal dengan beberapa istilah, yaitu: Classroom Research Hopkins.

Dalam melakukan penelitian ini peneliti tidak hanya hadir pada saat jadwal mengajar, melainkan selalu aktif memantau dan meneliti peserta didik sekalipun diluar jam pelajaran guna memaksimalkan hasil penelitian. dengan menggunakan pendekatan PTK, kedudukan peneliti dalam penelitian ini merupakan faktor yang sangat menentukan. Oleh karena itu, peneliti bertindak secara langsung sebagai pendidik dalam prosses pengumpulan data, maka peneliti harus terus berada daan terlibat langsung dalam penelitian dan objek yang akan diteliti.

Subyek dalam penelitian ini adalah peserta didik kelas VII-5 SMP Muhammadiyah Palangka Raya

\begin{tabular}{|c|c|c|}
\hline No & $\begin{array}{c}\text { Jenis Kelamin } \\
\text { Peserta Didik }\end{array}$ & $\begin{array}{c}\text { Jumlah } \\
\text { Peserta Didik }\end{array}$ \\
\hline 1 & Laki-laki & 17 \\
\hline 2 & Perempuan & 6 \\
\hline \multicolumn{2}{|c|}{ Jumlah } & 23 \\
\hline
\end{tabular}

Sumber: Absen SMP Muhammadiyah Palangka Raya.

Dalam penelitian tindakan kelas, analisis dilakukan peneliti sejak awal, pada setiap aspek kegiatan penelitian. Pada waktu dilakukan penelitian pencatatan lapangan melalui observasi atau pengamatan tentang kegiatan pembelajaran di kelas. Data yang dikumpulkan dari setiap siklus akan dianalisis menggunakan metode Mixed Methods atau metode kombinasi antara kualitatif dan kuantitatif.

Data kualitatif diperoleh dari hasil observasi dimaksudkan untuk mengetahui kekurangan dan kelebihan dari pembelajaran yang dilakukan, data kualitatif diperoleh dari aktivitas peserta didik dan guru dalam proses pembelajaran yaitu dengan cara menganalisis keaktifan bertanya peserta didik dan keefektifan pemelajaran yang dilakukan guru dengan menggunakan metode kooperatif tipe Team Games Tournament (TGT) Berbantuan Media Visual.

Data Kuantitatif adalah Tes hasil belajar yaitu untuk mengumpulkan data kuantitatif hasil belajar peserta didik pada pembelajaran IPS pra tindakan dan sesudah tindakan.

\section{HASIL DAN PEMBAHASAN}

Pada tahap ini peneliti melaksanakan tindakan pembelajaran menggunakan Model pembelajaran Kooperatif tipe team games tournament berbantuan Media visual.

1. Pengamatan aktivitas guru dan peserta didik

Tabel 1

Aktivitas Guru dan Peserta Didik

\begin{tabular}{|l|l|c|c|}
\hline No & Aktivitas & Siklus I & Siklus II \\
\hline 1 & Guru & 3,47 & 3,58 \\
\hline 2 & Peserta Didik & 2,36 & 3,36 \\
\hline
\end{tabular}

\section{Gambar 1}

Grafik Aktivitas Guru dan Peserta Didik

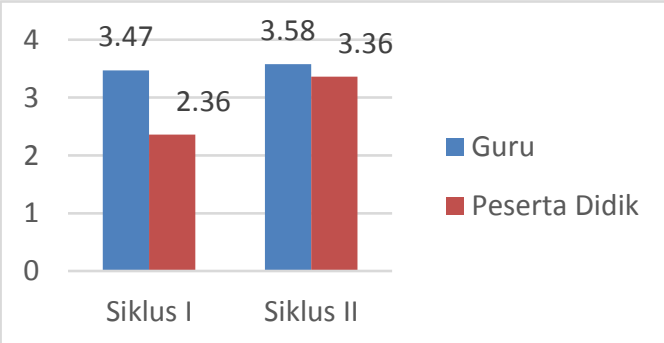

Dari data di atas maka dapat diketahui bahwa aktivitas guru dan peserta didik 
mengalami peningkatan disetiap siklusnya. Hal tersebut menunjukkan bahwa penggunaan Model pembelajaran Kooperatif tipe team games tournament berbantuan Media visual dapat digunakan dan tepat agar peserta didik aktif dalam proses pembelajaran.

2. Hasil belajar

Tabel 2

Nilai Hasil Belajar Peserta Didik

\begin{tabular}{|l|l|c|c|}
\hline \multirow{2}{*}{ No. } & \multicolumn{3}{|c|}{ Hasil Belajar } \\
\cline { 2 - 4 } & Nilai & $\begin{array}{c}\text { Rata- } \\
\text { rata }\end{array}$ & Ketuntasan \\
\hline 1. & $\begin{array}{l}\text { Tes } \\
\text { Awal }\end{array}$ & 39,34 & $4,34 \%$ \\
\hline 2. & Siklus I & 53,47 & $30,43 \%$ \\
\hline 3. & $\begin{array}{l}\text { Siklus } \\
\text { II }\end{array}$ & 81,30 & $91,30 \%$ \\
\hline
\end{tabular}

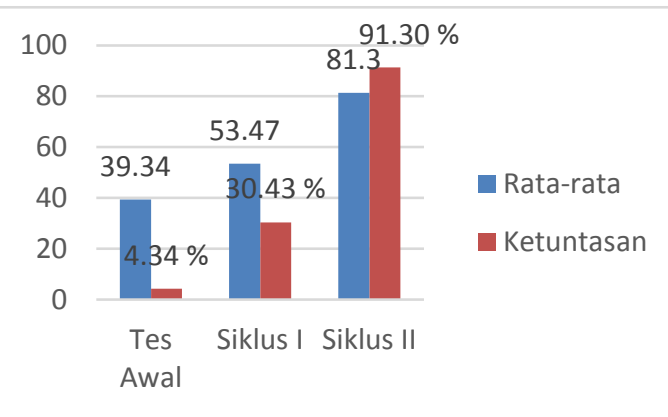

Gambar 2

Grafik Rata-rata Hasil Belajar Peserta Didik

Berdasarkan tabel dan grafik di atas maka dapat diketahui bahwa hasil belajar peserta didik mengalami peningkatan pada setiap siklusnya. Hal tersebut menunjukkan bahwa penggunaan Model pembelajaran Kooperatif tipe team games tournament berbantuan Media visual dapat digunakan dan tepat untuk meningkatkan hasil belajar peserta didik.

\section{KESIMPULAN}

Aktivitas belajar peserta didik dalam pembelajaran Ilmu Pengetahuan Sosial (IPS) dengan menggunakan model pembelajaran kooperatif tipe Team Games Tournament (TGT) berbantuan media visual lebih baik dengan kategorisasi aktif di kelas VII-5 SMP Muhammadiyah Palangka Raya Tahun Pelajaran 2016/2017, yaitu skor aktivitas belajar peserta didik pada siklus I dengan skor rata-rata 28,36, dan siklus II dengan skor rata-rata 33,36, sehingga aktivitas peserta didik pada siklus II sudah dikatakan baik atau telah mencapai indikator keberhasilan.

Ada peningkatan hasil belajar Ilmu Pengetahuan Sosial (IPS) setelah menggunakan model pembelajaran kooperatif tipe Team Games Tournament (TGT) berbantuan media visual di kelas VII-5 SMP Muhammadiyah Palangka Raya Tahun Pelajaran 2016/2017. Hal ini terlihat dari data hasil belajar peserta didik pada saat pre testmemperoleh nilai rata-rata 39,34, post test siklus I memperoleh nilai rata-rata 53,47 dan pada siklus II meningkatkan dengan nilai rata-rata menjadi 81,30.

\section{DAFTAR PUSTAKA}

Ahmadi. (2011). Strategi Pembelajaran Sekolah Terpadu Pengaruh Terhadap Konsep Pembelajaran Sekolah Swasta Dan Negeri. Jakarta: PT Prestasi Pustakaraya.

Anita, dkk. (2011). Model Pembelajaran Kooperatif. Surabaya: Pusat Sains dan Matematika Sekolah Unesa.

Azhar Arsyad. (2013). Media Pembelajaran. Jakarta: PT Raja 
BITNET Jurnal Pendidikan Teknologi Informasi, Februari 2018, Volume 3 Nomor 1 (17-22) http://journal.umpalangkaraya.ac.id/index.php/bitnet

Grafindo Persada.

Hamalik. (2007). Pengembangan Pendidikan IPS SD. Jakarta: Direktorat Jendral Pendidikan Tinggi Departemen Pendidikan Nasional.

Komalasari, Kokom. (2013). Pembelajaran Kontekstual Konsep dan Aplikasi. Bandung: PT. Refika Aditama.
Merry. (2015). Upaya meningkatkan hasil Belajar Matematika Menggunakan Media Kertas Berwarna Pada peserta Didik Kelas IV di SDS Kristen Parapah Kuala Kapuas tahun Ajaran 2014/2015. Skripsi: UM Palangkaraya.

Trianto. (2014). Model pembelajaran Terpadu. Jakarta: Bumi Aksara. 